\title{
Solid waste as electron donor for Sulfate reducing bacteria to prevent heavy metals pollution from acidic coal mine waste
}

\author{
Mingliang Zhang ${ }^{1, a,{ }^{*}, \text { Haixia Wang }}{ }^{1, b}$ \\ ${ }^{1}$ School of Resources and Environment, University of Jinan, China \\ a mlzhangsd@126.com, b21012187@qq.com
}

\begin{abstract}
Keywords: Coal mine waste, sulfate reducing bacteria, solid waste, heavy metal
Abstract. Sulfate reducing bacteria (SRB) was isolated from soil and applied for the remediation of heavy metals pollution from acidic coal mine waste. The result indicated that SRB could be used for the remediation of heavy metals pollution from acidic coal mine waste, based on sewage sludge, chicken manure and sodium lactate as carbon sources. It showed the leachate $\mathrm{pH}$ of coal mine waste was enhanced, the release amounts of heavy metal ions were reduced, and the generation of acid mine drainage from acidic coal mine waste was inhibited. It indicated that sulfate reducing bacteria not only effectively prevent heavy metal pollution of acidic coal mine waste, but also achieve the aim of using waste to treat waste and coal waste piles re-vegetation using chicken manure, sludge and other solid waste as carbon source.
\end{abstract}

\section{Introduction}

Coal mine waste is the solid waste generated from coal mining and washing process. The average production of coal mine waste is about $15 \%$ of coal production. Therefore, it is estimated that the annual production of coal mining waste is about 370 million tons, which accounts for a quarter of the total industrial solid wastes. There are about 8 billion tons of coal mining wastes stockpiled at 1700 waste dumps which occupied $15,000 \mathrm{hm}^{2}$ lands. Exposed to air and rainfall, heavy metal in coal mine waste is very easy to be released, and it will lead to the surrounding environment pollution and ecological disruption, which can pose a serious threat to ecological safety and sustainable development in mining area [1]. Particularly, sulfide-bearing coal mine wastes will produce acid mine drainage with strong aciditiy and high concentrations of heavy metals, which will lead to more serious threat to environment [2].

At present, the remediation methods of acid coal mine waste mainly include alkaline neutralization method and microbiological treatment. Microbiological treatment process can generate alkalinity by reducing sulfate to sulfide when supplied with suitable organic carbon, and cause metal precipitation as sulfides in low redox condition [3-4]. Microbial remediation research and practice on coal mine waste pollution have been carreid out. Kim (1999) provided an innovative approach to prevent the production of acidic leachate from mining waste piles by promoting the growth of sulfate-reducing bacteria (SRB) within the piles. During batch incubation of SRB, the dissolved concentrations of Cd, $\mathrm{Cu}, \mathrm{Ni}$, and $\mathrm{Zn}$ in the supernatant were decreased to undetectable levels [5].

Solid waste (e.g. sewage sludge, manure) can provide nutrients to promote re-vegetation and reclamation of coal mine waste piles [6-8]. Solid waste cover as oxygen barrier can help to prevent the oxidation of reactive sulfide minerals and help to create reducing condition for SRB activity [9-11]. Therefore, it would be benefical for the combined utilization of SRB and solide waste (e.g.sewage sludge, manure) to prevent the production of acidic leachate from coal mine waste. In this study, sewage sludge and chicken manure was used as carbon sources to promote SRB for treatment of acidic coal mine waste, in order to provide the basis for filed practice.

\section{Materials and Methods}

SRB and materials. SRB was isolated from soil at the urban site in Jinan city. SRB was cultivated in anaerobic conditions in modified Postgate $\mathrm{C}$ medium. Coal mine wastes were collected from a coal 
waste pile in western Chinese coal mine area. Sewage sludge was collected from Everbright sewage treatment plant (Jinan), and chicken manure was collected from one chicken farm in Shandong province, China.

Batch experiment. To analyse the removal efficiency of sulfate and heavy metals by SRB with sewage sludge and manure as carbon sources, the following batch experiments were conducted using sealed conical flasks: (1)50 g coal mine waste $+150 \mathrm{~mL}$ deionized water; (2) $50 \mathrm{~g}$ coal mine waste +3 $\mathrm{mL}$ sodium lactate $+5 \mathrm{~mL}$ of SRB inoculum $+150 \mathrm{~mL}$ deionized water; (3) $50 \mathrm{~g}$ coal mine waste +10 $\mathrm{g}$ sewage sludge $+5 \mathrm{~mL}$ SRB inoculum $+150 \mathrm{~mL}$ deionized water; (4) $50 \mathrm{~g}$ coal mine waste $+10 \mathrm{~g}$ chicken manure $+5 \mathrm{~mL} \mathrm{SRB}$ inoculum $+150 \mathrm{~mL}$ deionized water. All batch experiments were carried out in anaerobic conditions in a biochemical incubator $\left(30^{\circ} \mathrm{C}\right)$, and $\mathrm{pH}$, Eh and the concentrations of $\mathrm{SO}_{4}{ }^{2-}, \mathrm{Fe}, \mathrm{Mn}, \mathrm{Zn}$ were monitored.

Analytical methods. The $\mathrm{pH}$ and Eh of samples were measured immediately after collection. Sulfate concentration was determined using Dionex ICS-90 Ion Chromatography System (ICS-90, Shimadzu, Japan). The concentrations of $\mathrm{Fe}, \mathrm{Mn}$ and $\mathrm{Zn}$ were measured by Atomic Absorption Spectroscopy (AAS). Field emission scanning electron microscope (SEM, FEI Quanta FEG 250) was used for micro-morphology observation of the formed precipitates.

\section{Results and Discussions}

pH, Eh and sulfate concentration. The $\mathrm{pH}$ and Eh variation in different batch tests are shown in Fig.1 (a) and (b). The $\mathrm{pH}$ of the control treatment was 5.0-5.2, which showed slight acidity of coal mine waste. The Eh of the control treatment was $326-350 \mathrm{mV}$. On the contrary, the $\mathrm{pH}$ of solution with SRB treatment using sodium lactate, sewage sludge, and chicken manure as carbon sources increased to 6.7, 6.4 and 6.5, respectively. Due to the activity of SRB, Eh decreased to $-300,-224$ and $-240 \mathrm{mV}$, respectively. It suggested that SRB had the ability of growing in coal mine waste using sewage sludge and chicken manure as carbon sources.
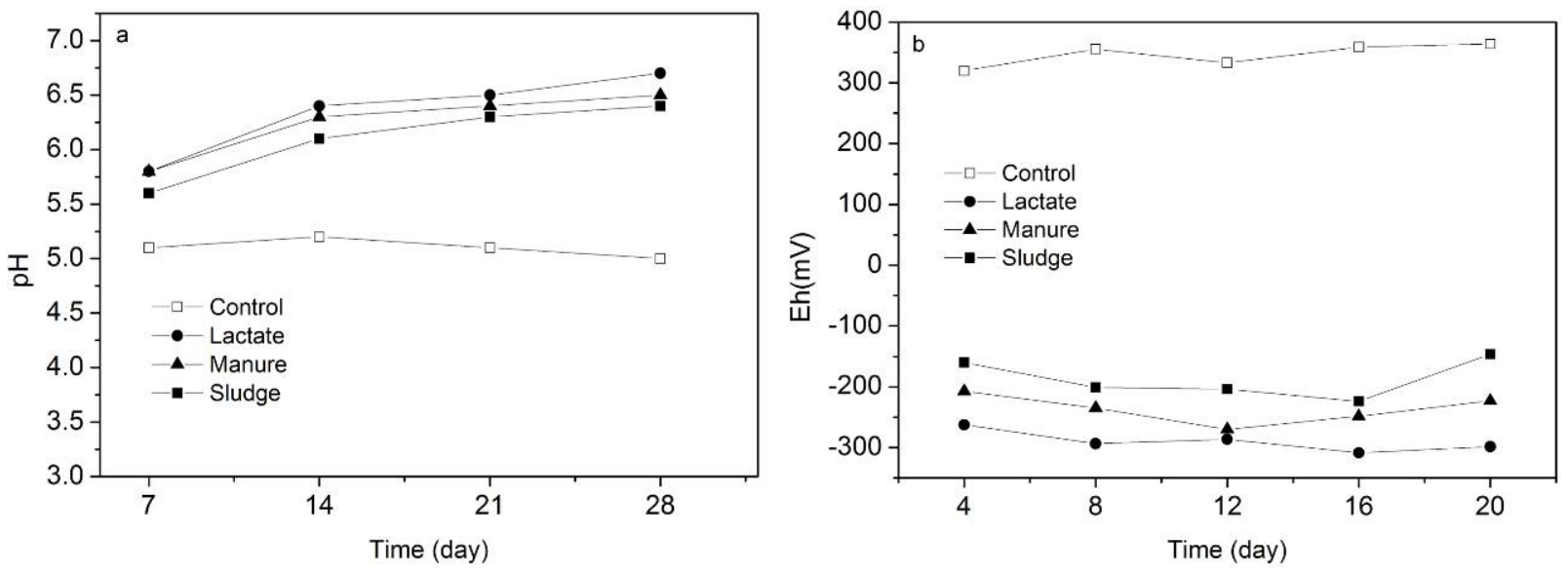

Fig. 1pH and Eh variation during the SRB remediation sysytem with lactate, sewage sludge and chicken manure as carbon sources

The sulfate concentration in different treatments is shown in Fig.2. In the control treatment, the sulfate was continuously released due to the soaking of coal mine waste, and the total concentration of sulfate increased from 4997 to $5759 \mathrm{mg} / \mathrm{L}$. In the treatment with sodium lactate, sewage sludge and chicken manure as carbon source, the sulfate concentration decreased to $882 \mathrm{mg} / \mathrm{L}, 2616 \mathrm{mg} / \mathrm{L}$ and $1741 \mathrm{mg} / \mathrm{L}$, respectively. The removal efficiency of sulfate was in the order of sodium lactate>chicken manure>sewage sludge. In different carbon sources, sodium lactate was the most efficient in different treatments, followed by chicken manure and sewage sludge. 


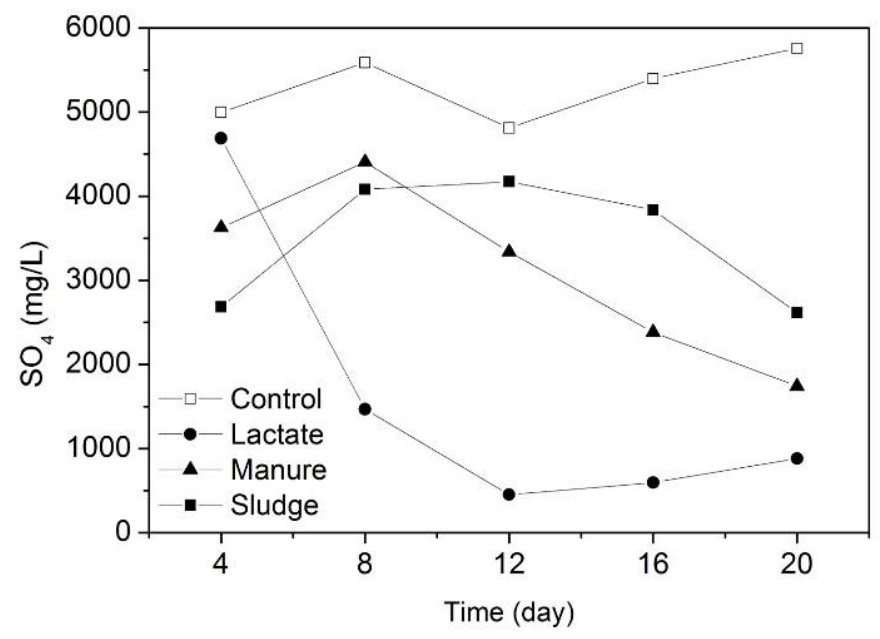

Fig. 2 Sulfate concentration variation during the SRB remediation sysytems
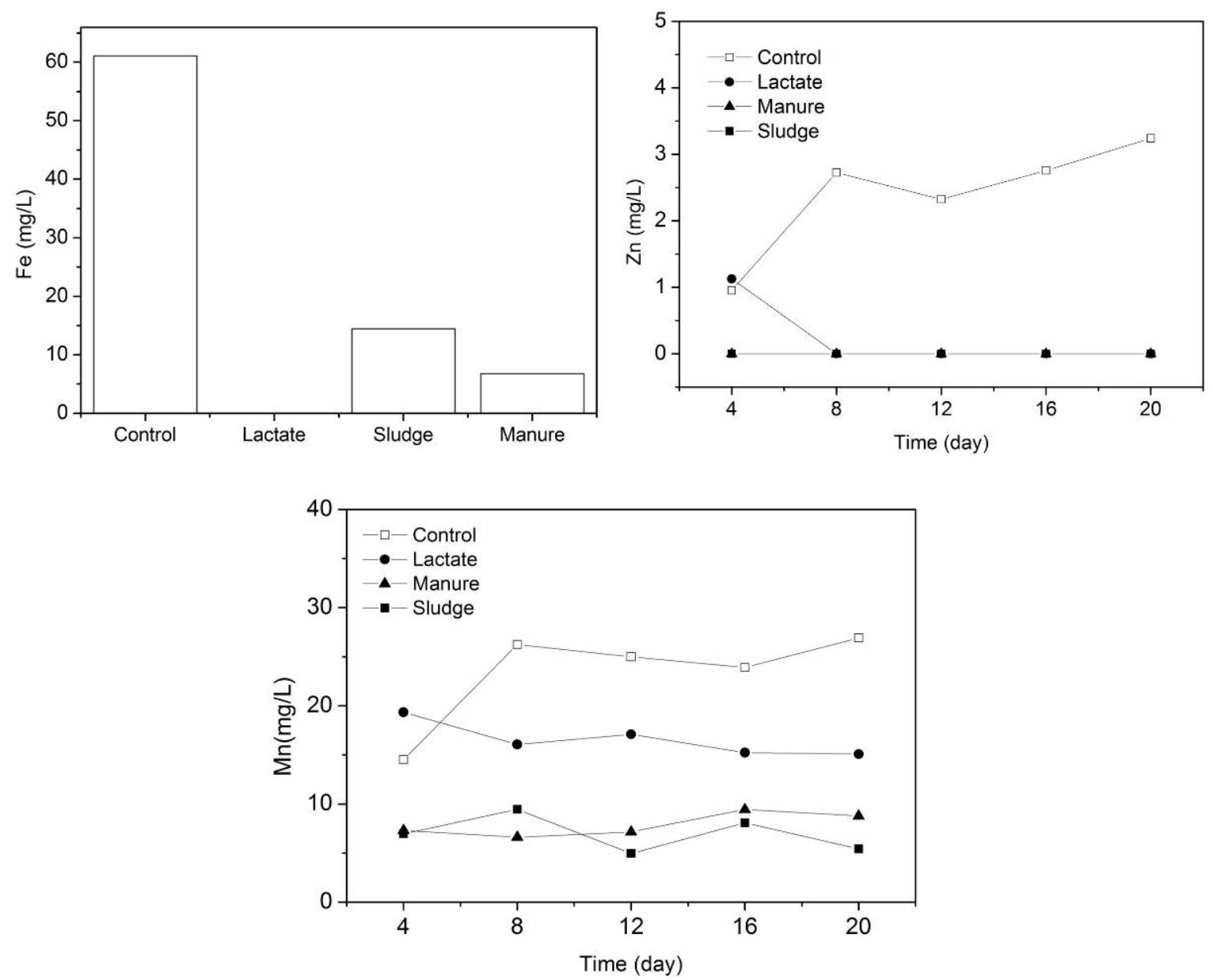

Fig. 3 Variation of the concentrations of Fe, $\mathrm{Zn}$ and Mn during the SRB remediation sysytems

Variation of metals. The heavy metal concentrations in different treatments is shown in Fig.3. The concentrations of $\mathrm{Fe}, \mathrm{Mn}$ and $\mathrm{Zn}$ in control treatment increased on the whole from first day to 20th day, due to metal ions release from coal refuse. The concentration of $\mathrm{Zn}$ increased from 0.95 to $3.24 \mathrm{mg} / \mathrm{L}$, and the concentration of $\mathrm{Mn}$ increased from 14.51 to $26.92 \mathrm{mg} / \mathrm{L}$. While, the concentration of $\mathrm{Zn}$ in the SRB treatment with sodium lactate as carbon source decreased from $1.13 \mathrm{mg} / \mathrm{L}$ to below dectection limit, and the concentrations of $\mathrm{Zn}$ in the SRB treatment with sewage sludge and chicken manure were below dectection limit. The concentration of Mn in SRB treatment with sodium lactate as carbon source reduced from 19.34 to $15.08 \mathrm{mg} / \mathrm{L}$, and the concentrations of $\mathrm{Mn}$ in the SRB treatment with 
sewage sludge and chicken manure were 4.96-9.45 mg/L and 6.61-9.43 mg/L, respectively. The results indicated that using chicken manure and sewage sludge as carbon sources SRB prevented heavy metal pollution of acidic coal mine waste.

\section{Conclusions}

Sulfate reducing bacteria (SRB) was isolated for the remediation of heavy metals pollution from acidic coal mine waste. The result showed the $\mathrm{pH}$ of coal gangue leachate was enhanced, the release amounts of heavy metal ions were reduced, and the generation of acid mine drainage from acidic coal gangue was inhibited. The results indicated that using chicken manure and sewage sludge as carbon sources, SRB not only prevented heavy metal pollution of acidic coal mine waste, but also achieved the aim of using waste to treat waste and coal waste piles re-vegetation.

\section{Acknowledgements}

This research was financially supported by Shandong Provincial Key Research and Development Program (2015GSF117014).

\section{References}

[1]H.T. Q.Kieu, E.Muller, H.Horn: Water Res. Vol 45(2011), p. 3863-3870.

[2]P.F.Costa, L.P. Matos, V.A.Leão, M.C.Teixeira: J.Environ.Chem.Eng.Vol 2(2014), p.70-75.

[3]D.B. Johnson, K.B.Hallberg: SCI Total Environ, Vol 338(2005), p.3-14.

[4]T.Hao, P.Xiang, H.R.Mackey, K.Chi, H.Lu, H.K. Chui, M.C.M. van Loosdrecht, G.H.Chen: Water Res.Vol 65(2014), p.1-21.

[5]S.D.Kim, J J.Kilbane II, D K.Cha: Environ Eng Sci.Vol 16 (1999), p.139-145

[6]J E.Halofsky, L H.McCormick: Environ Manage. Vol 35(2005), p. 569-578.

[7] M. Altun, E.Sahinkaya, I.Durukan, S. Bektas, K.Komnitsas: J hazard Mater. Vol 269(2014), p.31-37.

[8]R P.Choudhary, A S.Sheoran: Miner Eng. Vol 39(2012), p.29-35.

[9] A. Akcil, S. Koldas: J. Clean. Prod.Vol 14 (2006), p. 1139-1145.

[10] K.R.Waybrant, C.J.Ptacek, D.W.Blowes: Environ. Sci. Technol. Vol 36(2002), p. 1349-1356.

[11] T.W.Hao, P.Y.Xiang, H.R.Mackey, K.Chi, H.Lu, H.K.Chui, M.C.M, van Loosdrecht. G. H.Chen: Water Res. Vol 65(2014), p. 1-21. 